\title{
IMPERATIVE OF EXCHANGE RATES POLICY AND INDUSTRIAL GROWTH IN NIGERIA: A TIME SERIES ANALYSIS
}

\author{
Olatunji A. SHOBANDE ${ }^{1}$
}

DOI: 10.1515/tjeb-2017-0012

This paper looks at the impact of foreign exchange rate policies on industrial growth in Nigeria between 1981 and 2016. The study employed the Vector Error Correction Model (VECM) techniques, following the results of Johansen Cointegration techniques that shows the existence of long run relationship among the variables considered. While, VECM estimates showed that money supply (monetary policy) impacted positively effects, evidence on, TAX (fiscal policy) impacted negative on industrial growth. Besides, the Exchange rate and Inflation impacted negatively on industrial growth., suggesting that the issue of stability remained a challenge unresolved by the Apex bank. The emanating policy antidotes are that there is urgent need to use proactive monetary policy through money supply to speed up the rate of industrial growth on one hand, while providing tax incentive to various industrial good that can further have enhanced the contribution of the sector to industrial growth on the other. In all, the need to align the objective of exchange rate policy with broader macroeconomic goals is necessary for effective policy transmission mechanism to speed up the rate of industrial progress in the country.

\section{Keywords: \\ Exchange rate, Industrialisation, Export, Inflation}

\section{JEL Classification: L00, L16, F31}

${ }^{1}$ PhD Student, Department of Economics, Faculty of Social Sciences, University of Lagos, Nigeria 
Shobande, 0.A. (2017).

Imperative of Exchange Rates Policy and Industrial Growth in Nigeria: A Time Series Analysis

\section{Introduction}

In the years, just after the Second World War, it was widely acknowledged by governments that achieving realistic and stable exchange rate brings along lots of economic benefits such as improvement of allocative efficiency, enhancement of industrial competitiveness, productivity growth, promotion of domestic price stability and internal balance (Jimoh, 2014). This phenomenon also engenders appreciable growth of foreign exchange earnings, as well as, substantial net capital inflow and balance of payments equilibrium (Mordi, 2014 and Amassoma and Odeniyi, 2016). The experience of the inter-war years had been of severe cycles in real activity and it seems obvious that devaluations and exchange rate instability had contributed to decrease in industrial growth (Oshikoya, 2014).

In Nigeria, under the flexible exchange rate system, the CBN use foreign market option for regulating the economy. In floating exchange rate system, the CBN allows the Foreign Exchange Market (FEM) to adjust freely in response to the force of demand and supply. These actions increase the time inconsistency problem and exchange rate volatility. This is usually adopted to cushion inflationary pressure by exchange rate at the expense of foreign country, thus achieving an appreciation of domestic currency. In fixed exchange rate system, the exchange rate between a country's currency and all other currencies are fixed by the government acting through its monetary authority (Duke 2009).

In the exact literature, monetary policy affects the exchange rate through two channels: fundamental exchange rate volatility and credibility. While the CBN managed volatility by using currency intervention policy or using a monetary policy oriented rates. Apparently, a tight monetary policy in an open economy with flexible exchange rate system increases domestic interest rate which requires currency depreciation until equilibrium is attained (Aliyu, Yakub, Sanmi, and Duke 2009).

As it were, emphasis is placed on the objective of discouragement of excess foreign exchange demand or expansion of foreign exchange supply especially from non-oil and industrial exports, and on the stability of the exchange rate (Omisakin, 2009, Jimoh, 2014, and CBN,2014, 2016; Anyanwu, Anawude and Okoye, 2017). On the account of the foreign exchange crisis precipitated by sudden decline in the dominant crude oil earnings experienced in the early $80 \mathrm{~s}$ and consequent failure to realize the objectives of foreign exchange management policies despite the various exchange control measures, the Federal Government in September 1986, through the Structural Adjustment Programme (SAP), resorted to "market-determined" exchange rate (Eregha, 2017). This started with introducing the Second-Tier Foreign Exchange Market (SFEM) where the exchange rate and foreign exchange allocation for private sector would be freely determined by the forces of demand, given the foreign exchange supply by Central Bank of Nigeria (CBN) (Unugbro (2007). 
Shobande, 0.A. (2017).

Imperative of Exchange Rates Policy and Industrial Growth in Nigeria: A Time Series Analysis

In other words, the "market-determined" exchange rate is through the forces of demand, while CBN monopolistically determines the supply of foreign exchange on a weekly basis. So, there are little or no private sector forces of supply, the supply of foreign exchange coming almost exclusively from crude oil export earnings channeled through CBN (CBN, 2010). The relatively little foreign exchange supply from private sector was through Bureau de change, which was introduced in 1989 for dealing in private sources of foreign exchange and selling freely to small users (CBN, 2016).

Obviously, the exchange rate policy has a long history in Nigeria. Between 1959 and 1967, Nigeria implemented fixed exchange parity exclusive using the British pound and this was abrogated in 1972 (Adeoye and Shobande, 2016, 2017 and CBN, 2016). The aftereffects of the devaluation of pound in 1967 and the onset of a powerful US dollar led to the insertion of US dollar in the exchange rate parity (Oke, Bokana and Shobande, 2017; Shobande and Alimi, 2015 and Shobande and Ojeleye, 2015). In 1979, the Central bank reverted to import weighted basket of currency method which was considered due to the tie of currencies: US dollar, British Pounds, Japanese Yen, French Franc, German Mark, Swiss Franc and Dutch guilder (Mordi, 2014; Abolo, 2014, and Adedipe, 2014). In sum between 1980 and 2016, the fixed and floating exchange rate systems were used interchangeably (CBN, 2016).

The pertinent concern of this paper is to examine the impact of exchange rate policy on industrial growth in Nigeria. The paper inquires whether exchange rate stability and macroeconomic policy matter for industrial growth in Nigeria. While a number of interesting variables have emerged to test various hypotheses to prescribe strategies to enhanced industrial progress, this paper hopes to contribute to the existing literature on exchange rate risk by analyzing the three dimensions in the Nigeria context. First, we look at the scenario for accessing the present exchange rate policy, which determines the necessary but not sufficient conditions for successful investment in industrial sector; the second adopts appropriate dataset using the VEC econometric techniques to analyze empirical results and options for a long-term industrial development.

The remaining part of this paper is broken into five segments. Next it starts with segment 2 provides a synopsis of the literature review. Following is the theoretical framework and methodological approaches in part 3. Results of the study are presented and discussed in part 4 while section 5 contains the conclusion including policy suggestions.

\section{Literature Review}

It is not an overstatement to suggest that the issues related to the development oriented exchange rate policy, its evolution overtime and its position relative to industrial growth now occupies a central role in academic and policy debate on long term growth and developmental 
Shobande, 0.A. (2017).

Imperative of Exchange Rates Policy and Industrial Growth in Nigeria: A Time Series Analysis

strategies (Jeanne and Korinek, 2010, Blanchard, 2017). While exchange rate can be used to pursue an appropriate level of international competitiveness and economic growth anchored on domestic prices, the appropriate exchange rate policy option remained controversial and inconclusive (Shobande and Alimi, 2015; Adeoye and Shobande, 2017). There are several theories that attempt to explain the relationship between exchange rate and industrial growth.

The first theoretical approach is the Purchasing Power Parity (PPP) that suggested that the exchange rate between two currencies of a given period are equal if the ratio of the price level of a fixed quantity of good and services are equal (Chipeta, 2017; Anyawu, Anawude and Okoye, 2017, and CBN, 2016). This theory is built on the premise that increase in domestic prices must be accompany by depreciation in it currency to resuscitate PPP (Mordi, 2014).

The second is the monetary model of exchange rate that gives credit to sticky price mode, flexible price monetary model and real interest rate differential rooted in the demand and supply of money as a determinant of exchange rate policy guide. The third is the recent celebrated model of Obstfeld and Rogoff which is an extension of the PPP model. The Obstfeld and Rogoff model suggested that the exchange rate pass through consumer prices to affects industrial growth (Aliyu, Yakub, Sanmi, and Duke 2009; Gluzmann, et al, 2012 and Ocam po, 2015).

There is an extensive empirical literature on the impact of exchange rate policy on industrial growth with diverse results. The diversity arises from methodologies, measurement of variables as well as country studied. In terms of empirical evidence with developing countries, Aghion et al (2006) examined the impact of significant change in exchange rate on output growth, using a data set of 83 countries between 1960 and 2000. The study concluded that there is a long run relationship between changes in exchange rate and increase in productivity. Schnabel (2008) studied the effect of exchange rate stability on economic growth in 41 European countries, using advanced panel analysis. The study observed that international capital flow and macroeconomic policy are major transmission mechanism on which exchange rate stability affects economic growth. This result is contrary to Mireille (2007), who argued that over-valuation of exchange rate is a major setback in growth plan and economic recovery of Nigeria and Benin Republic.

In a related study of Khataee and Mousavi (2008) examined the effect of exchange rate fluctuation on the level of economic growth, anchored on the premise of the financial market development. The author utilized a five year mean data from a sample of 69 countries, to establish this relationship. The result of this study shows that inefficiency in the financial system is a major factor affecting low level of productivities and fluctuation in exchange rate, among the countries observed. Toulaboe (2011) observed the relationship between real 
Shobande, 0.A. (2017).

Imperative of Exchange Rates Policy and Industrial Growth in Nigeria: A Time Series Analysis

exchange rate misalignment and economic growth among 33 developing countries and concluded that there is a negative relationship between exchange rate fluctuation and economic growth.

In a similar study, Rodrik (2008) established that there is a weak relationship between exchange rate and market failure, which is often caused by under investment in the financial market and traded goods sector. The result of Rodrik (2008) was further confirmed by Di Nino et al (2011) who further established that nominal depreciation of the exchange rate has continuous real effect on industrial growth. While this is contrary to Gluzmann et al (2012) who established that a weak exchange rate often leads to higher savings and investment through income redistribution. The study further established that under devaluation does not affect the tradable sector. On the other hand, Nouira and Sekkat (2012) find no evidence that under devaluation of exchange rate has impact on industrial growth among developing countries examined.

Conversely, most studies on the impact of exchange rate stability and growth in Nigeria documented instructive results. Egwaikhide, Adeniyi and Olanipekun (2014) in their study on the relationship between monetary aggregates and the exchange rate under alternative exchange rate regime in Nigeria. the finding of their study suggests that domestic economic management policies should be proactively orchestrated to better align the objective of exchange rate policy with broader macroeconomic goals. This is consistent with Adeyemo (2014) who also observe that there are challenges with respect to the best method the exchange rate stability can achieved, since there is limitation to what monetary policy could achieve on its own.

Therefore, judging from the existing literature, the questions of convergence in potential of exchange rate stability and industrial growth remains scarce. While two major questions remained unsettled in the existing literature: First is the extent to which the current quest for exchange rate stability can enhance industrial growth? On a second note, the issue of whether the current economic policies and strategies have can enhance industrial development remained unresolved, which is the motivation behind this paper.

\section{Methodology}

\subsection{Theoretical Architecture}

The theoretical model that postulates the impact of the exchange rate over the industrial growth has the roots in the relationship between the nominal demand for money that positively related with nominal national income but inversely related to nominal interest rate. The theory shows that an excess demand for money means that an appreciation of the nation currency which may lead to the loss of competitiveness, imports will increase and it will be a 
substitution between foreign good and domestic goods that could affect the level of industrial growth. The hypothesis maintains that any country that wants to depreciate its exchange rate by value should reduce its interest rate by the right amount (See Blanchard, 2009, 2015, 2017). The justification for this consideration is based on the possibility of that lower interest rate can exert increase in investment which in turn can translate to industrial growth (Adeoye and Shobande, 2017 and Anyanwu, Anawude and Okoye, 2017, CBN, 2016).

\subsection{Model Specification}

Drawing from Blanchard, Adler and Filho (2015) model on foreign exchange intervention exchange rate pressures nexus, which was adapted by Anyanwu, Anawude and Okoye, (2017), our model is specified as:

$$
I N D_{t}=\beta_{0}+\beta_{1} E X_{t}+\beta_{2} I N T_{t}+\beta_{3} M S_{t}+\beta_{4} T O_{t}+\beta_{5} I N F_{t}+\beta_{6} T A X_{t}+\varepsilon_{t}
$$

Where: IND is measure as Manufacturing Value Added; EX is measure as real exchange rate obtained by adjusting for relative price between domestic and foreign countries (United State CPI was used for foreign); TO proxy as Trade Openness, INT as real interest rate (monetary policy); MS is Money Supply (monetary policy); INF is inflation rate proxy as Consumer Price Index (CPI) (Captured: macroeconomic uncertainty); TAX proxy as Value added tax (fiscal policy), $t$ is time; $\beta_{0}$ is intercept or constant; $\beta_{1-6}$ are parameters of the explanatory variables; and $\varepsilon$ is error term.

The apriori expectation provides expected signs and significance of the values of the coefficient of the parameters under review on the part of the empirical evidence and theoretical assertions. All the selected indicators are theoretically expected to contribute to industrial output growth rate positively, excluding inflation which is expected to retard industrial output growth rate negatively.

All the data were sourced from the Central Bank of Nigeria's statistical bulletin, volume 26, 2016 and World development indicator (WDI), 2016. The period of study covers from 1981 to 2016 .

\section{Empirical Results \& Discussion}

\subsection{Unit Roots Test}

The unit root estimates were based on Dickey Fuller-GLS test and N.G Perron the result is presented in table 1. From the table, it was observed that all the variables were I (1) series. 
Shobande, 0.A. (2017).

Imperative of Exchange Rates Policy and Industrial Growth in Nigeria: A Time Series Analysis

Table 1a. Pre Test A: DF-GLS Unit Root Test

\begin{tabular}{|c|c|c|c|}
\hline \multicolumn{4}{|c|}{ Dickey Fuller-GLS (DF-GLS) Test } \\
\hline Variable & Level & 1st Difference & Status \\
\hline IND & -0.0020 & $-2.9832 * *$ & $\mathrm{I}(1)$ \\
\hline EX & -0.3680 & $-7.367 *$ & $\mathrm{I}(1)$ \\
\hline INT & -1.4720 & $-7.4096 *$ & $\mathrm{I}(1)$ \\
\hline MS & -0.6433 & $-58967 *$ & $\mathrm{I}(1)$ \\
\hline TO & -0.6695 & $-5.0013 *$ & $\mathrm{I}(1)$ \\
\hline INF & -05261 & $-9.3476 *$ & $\mathrm{I}(1)$ \\
\hline TAX & -0.9486 & $-4.2585 *$ & $\mathrm{I}(1)$ \\
\hline Critical Values & Level & 1st Difference & \\
\hline $1 \%$ & -3.5925 & -3.5966 & \\
\hline $5 \%$ & -2.9314 & -2.9332 & \\
\hline $10 \%$ & -2.6039 & -2.6049 & \\
\hline
\end{tabular}

Note: $*=1 \%$ and $* \star=5 \%$ significance level.

Source: Author Computation, 2017.

Table 1b. Pre-Tests 2: Results of NG-Perron Unit Root

\begin{tabular}{ccccc}
\hline Variables & $\mathbf{M Z}_{\mathbf{a}}$ & $\mathbf{M Z}_{\mathbf{t}}$ & $\mathbf{M S B}$ & $\mathbf{M P T}$ \\
\hline \multicolumn{5}{c}{ Data } \\
\hline IND & -5.23656 & -1.59848 & 0.30525 & 4.72979 \\
EX & -4.21549 & -1.25882 & 0.22113 & 2.40292 \\
INT & -3.25748 & -1.27492 & 0.39138 & 27.9457 \\
MS & -3.53775 & -1.10508 & 0.31237 & 6.88651 \\
TO & -1.60688 & -0.62750 & 0.39051 & 10.9398 \\
INF & -3.27490 & -1.88724 & 0.17238 & 5.48017 \\
TAX & -3.83239 & -1.36936 & 0.35731 & 6.40159 \\
\hline \multicolumn{5}{c}{ First Difference Data } \\
\hline$\Delta$ IND & -14.5846 & -2.69960 & 0.18510 & 1.68297 \\
$\Delta$ EX & -16.3493 & -2.85761 & 0.17478 & 1.50420 \\
$\Delta$ INT & -16.8776 & -2.90347 & 0.17203 & 1.45711 \\
$\Delta$ MS & -17.5201 & -2.92110 & 0.16673 & 1.53836 \\
$\Delta$ TO & -16.2506 & -2.85035 & 0.17540 & 1.50816 \\
$\Delta$ INF & -32.9119 & -4.05655 & 0.12325 & 2.76901 \\
$\Delta$ TAX & -15.4737 & -2.78152 & 0.17976 & 1.58334 \\
\hline \multicolumn{5}{c}{ Critical Valuesa } \\
\hline 1\% & -13.8000 & -2.58000 & 0.17400 & 1.78000 \\
5\% & -8.10000 & -1.98000 & 0.23300 & 3.17000 \\
10\% & -5.70000 & -1.62000 & 0.27500 & 4.45000 \\
\hline
\end{tabular}

Note: $*, * * * * *$ show significant at $1 \%, 5 \%$ and $10 \%$ level respectively. a: asymptotic critical value taken from NgPerron: Modified Philips-Perron test. : Modified PP t-test. MSB: Modified Sargan-Bhargava test. MPT: Modified Point Optimal test.

Source: Author Computation, 2017. 
Shobande, 0.A. (2017).

Imperative of Exchange Rates Policy and Industrial Growth in Nigeria: A Time Series Analysis

$\mathrm{Ng}$-Perron unit root test also confirmed that all seven variables are stationary at their first difference. However, this result also suggests that all seven variables are integrated in the same order, i.e. I (1).

\subsection{Co-integration Test}

A co-integration test was performed using the Johansen (1988) approach to find out the existence or inexistence of a long-run relationship among the variables employed for this study and the results are presented in Table 2. It was observed that the null hypothesis of no cointegration for $r=0$ was rejected by the trace and maxi-eigen tests because the statistical values were greater than the critical values while the null hypothesis of no cointegration for $r \leq 1$ was not rejected by both tests because the statistic values were less than the critical value, suggesting the existence of one cointegration equation. Thus, the trace and maxi-eigen statistical assert the existence of a long run relationship among the variables in equation (1).

Table 2. Summary of the Co-Integration Estimate

\begin{tabular}{|c|c|c|c|c|c|c|c|}
\hline & \multicolumn{3}{|c|}{ Trace Test } & \multicolumn{4}{|c|}{ Maximum e-gen Value Test } \\
\hline Null & Alternative & Statistics & $\begin{array}{c}0.05 \text { Critical } \\
\text { Values }\end{array}$ & Null & Alternative & Statistics & $\begin{array}{c}0.05 \text { Critical } \\
\text { Values }\end{array}$ \\
\hline$r=0$ & $r \geq 1$ & 139.79 & 125.62 & $r=0$ & $r=1$ & 67.20 & 46.23 \\
\hline$r \leq 1$ & $r \geq 2$ & 72.59 & 95.75 & $r \leq 1$ & $r=2$ & 23.64 & 40.08 \\
\hline$r \leq 2$ & $r \geq 3$ & 48.96 & 69.82 & $r \leq 2$ & $r=3$ & 19.31 & 33.88 \\
\hline
\end{tabular}

Source: Author Computation, 2017

\subsection{Normalized Cointegration Coefficient: Long Run Regression Estimates}

Sequel to the existence of cointegration among the variable in equation (1), this study proceeds to estimate the normalized long run regression on the relationship between exchange rate policy and industrial growth in Nigeria. Table 3 shows the outcome of the results.

Table 3. VEC Normalised Long Run Regression Estimate Analysis

\begin{tabular}{ccccccc}
\hline & \multicolumn{7}{c}{ Independent Variables } \\
\hline & LEX (-1) & LINT(-1) & LMS(-1) & LTO(-1) & LINF(-1) & LTAX(-1) \\
Coefficient & -0.339 & -1.229 & 0.485 & 0.603 & -0.587 & -0.788 \\
t-statistics & -2.034 & $-2034^{* *}$ & 1.272 & 1.162 & -2.260 & $5.678^{*}$ \\
\hline
\end{tabular}

Source: Author Computation, 2017 
Shobande, 0.A. (2017).

Imperative of Exchange Rates Policy and Industrial Growth in Nigeria: A Time Series Analysis

It was evidence from the long run estimates that there exists a differential impact of exchange rate stability on industrial inclusiveness in Nigeria. While, the Exchange rate and Inflation impacted negatively on industrial growth, suggesting that the issue of stability remained a challenge unresolved by the monetary authority. Similarly, monetary policy captured with money supply (MS) and Interest rate (INT) present two differential results. Despite the fact there is a positive relationship between money supply (MS) and industrial growth, Interest rate (INT) affected industrial growth negatively. Further evidence show that Fiscal Policy (Value Tax) impacted negatively while, trade openness has positively influences industrial growth in Nigeria. The policy implication of these result is that significant depreciation of exchange rate would have a pronounced effect on domestic price level. In the light of this sharp depreciation should be avoided due to its impact on domestic industrial growth. It is evident from the above result that the current policy environment is not favorable for industrial growth as it were, since both monetary and fiscal policies present dismal results.

\subsection{Post Test: Residual Diagnostic Results}

Further analysis was carried out to check the normalized VEC regression estimates using the serial correlation LM test, Chi-square and Normality test. All presented in table 4.

Table 3. Post Tests: Residual Diagnostic Tests.

\begin{tabular}{cccc} 
& Serial Correlation Test & Heteroskedasticity Test & Normality Test \\
\cline { 2 - 4 } Source: & Author Computation, 2017 & &
\end{tabular}

Evidently, the results of the serial correlation LM test confirmed the absence of serial correlation in the residual of the VEC estimate. This is because the values of the LM statistics at various lag were not significant, suggesting that residual were conditionally normally distributed, and the estimate can be used for policy inference.

\section{Conclusions and Recommendations}

This study examined the transmission mechanism to which the present exchange rate stability affects industrial growth in Nigeria between 1981 and 2016. The econometrics technique was anchored based on the Johansen co-integration technique which suggest existence of long run relationship among the variables considered. Based on the results, it's obvious that exchange rate stability is necessary for ensuring quicken the pace of industrial growth in Nigeria on one hand, while, the current exchange rate policy needs to encourage proper coordination between monetary and fiscal policies, putting emphases on stability, is urgently required on the other hand. Therefore, the need to align the objective of exchange rate policy with broader macroeconomic goals is necessary for effective policy transmission mechanism to speed up the rate of industrial progress in the country. 
Shobande, 0.A. (2017).

Imperative of Exchange Rates Policy and Industrial Growth in Nigeria: A Time Series Analysis

\section{References}

Abolo, E.M (2014) "Dollarisation-Any Possibility in Nigeria and its Effects on Economic Management and Exchange Rate Volatility" Economic and Financial Review, 52(4), 125-155.

Adedipe, B. (2014) “Exchange Rate, Capital Flows and Monetary Policy: Lesson from Emerging Market Economies" Economic and Financial Review, 52(4), 155-181.

Adeoye, W.B and O.A Shobande (2017) "Monetary Transmission Mechanism and Macroeconomic Aggregates in Nigeria" Caleb Journal of Social and Management Sciences, Caleb University, Lagos. Vol.

Adeoye, W.B and O.A Shobande (2016) "Emergence of the New Monetary Policy Mandate and Macroeconomic Shock: A VAR Approach". Journal of Economic policy and Development. Department of Economics, University of Lagos. 1(1), 47-56.

Adeoye, W.B and O.A Shobande (2015) "Exchange Rate Stability and Economic Growth in Nigeria: Exploring a new Dimension". Nigeria Journal of Social Sciences, University of Lagos. 31(2).

Adeyemo, A. (2014) "Foreign Exchange Rate Market Segmentation, Foreign Exchange Utilization and Exchange Rate: The Nigeria Experience" Economic and Financial Review, 52(4), 53-71.

Aghion, P, P. Bacchetta, R. Ranciere and K. Rogoff (2006) Exchange Rate Volatility and Productivity Growth: The Role of Financial Development, NBER Working Paper.

Amassoma, D. and B. Odeniyi (2016) "The Nexus between Exchange Rate Volatility and Economic Growth on Nigeria" Singaporean Journal of Business Economics and Management Studies. 4(12), 8-28.

Anyanwu, F.A, A.C Awanwude, N.T Okoye (2017) “Exchange rate policy and Nigeria's Economic Growth: A Granger Causality Impact Assessment" International Journal of Applied Economics, Finance and Accounting. 1(1), 1-13.

Aliyu, U, R, M.U. Yakub, G.K Sanmi and O.O Duke (2009) Exchange Rate Pass-through in Nigeria: Evidence from a Vector Error Correction Model. Paper presented at the CSAE Conference, Oxford University, UK.

Blanchard, O. (2017) “Distortions in Macroeconomics" 2017. 1-8

Blanchard, O., G. Adler and I. Filho (2015) "Can Foreign Exchange Intervention Stem Exchange Rate Pressures from Global Capital Flow Shocks" NBER series. 2-37.

Blanchard, O. (2009) "The State of Macro" Annual Review of Economics, 1: 209-228, 2009

CBN (2010), Central Bank of Nigeria Report. CBN publication.

CBN (2013), Central Bank of Nigeria Statistical Bulletin. CBN publication.

CBN (2015), Central Bank of Nigeria Statistical Bulletin. CBN publication.

CBN (2016), Central Bank of Nigeria Report. CBN publication.

Central Bank of Nigeria (2016) "Foreign Exchange Rate" Research Department, CBN, Education in Economic series, No. 4 (2016).

Chipeta, C, D.F. Meyer, P. Muzindusti (2017) "The Effect of Exchange Rate Movements and Economic Growth on Job Creation" De Gruyter. 62(2), 20-47.

Di Nino V, Eichengreen B and M Sbracia (2011) "Real Exchange Rates, Trade, and Growth: Italy" Banca d'Italia, Economic History Working Papers No 10. 
Shobande, 0.A. (2017).

Imperative of Exchange Rates Policy and Industrial Growth in Nigeria: A Time Series Analysis

Egwaikhide, F. O, M. Oyinlola, O. Adeniyi and D.B Olanipekun (2014) "Empirical Exposition of Monetary Policy under A flexible and Managed Float Exchange Rate Regime for Nigeria" Economic and Financial Review, 52(4), 13-29.

Eregha, P.B (2017) "Exchange Rate Policy and FDI in WAMZ" African Development Bank Group. Working Paper series, no: 254.

Gluzmann, P A, Levy-Yeyari, E, and F Sturzenegger (2012) "Exchange Rate Undervaluation and Economic Growth" Diaz Alejandro (1965) revisited" Economics Letters 117(3), 666-672.

Jimoh, A. (2014) "Exchange Rate Policy and Economic Management: A Theoretical Nexus" Economic and Financial Review, Vol. 52 (4), 13-57.

Jeanne, O. and A. Korinek (2010) "Excessive Volatility in Capital Waves: surge, stop, flight, and retrenchment. Journal of International Economics 88 (2002) 235-251.

Johansen, S. (1988) "Statistical Analysis of Cointegration Vectors, Journal of Economics Dynamics and Control 12(2-3), 231-254.

Khatee, M. and N.S Mousavi (2008) "Effect of Exchange rate Fluctuations on the Economic Growth Given the Level of Financial Market Development. Journal of Economic Researches Iran, 10(37), 1-19.

Mireille L. (2007) "The Impact of Real Exchange Rate on Manufacturing Exports in Benin", Africa Region Working Paper Series No 107.

Mordi, C.N (2014) Exchange rate and Inflation: is a Link. Economic and Financial Review, Vol. $52(4), 71-105$

Nouira R and K Sekkat (2012) Desperately Seeking the Positive of Undervaluation on Growth, Journal of Macroeconomics 34(2), 537-552.

Ocampo, J. A (2015) "Capital Account Libralisation and Management" UNU WIDER Working Paper, 2015/48, May

Omisakin, O.A(2009) "Exchange Rate Pass Through Domestic Price and Output in Nigeria" Journal of International Business Management, 3(1), 38-42

Oke, D.M, K. G Bokana and O. A. Shobande (2017) "Re-examining the Nexus between Exchange and Interest rates in Nigeria" Presented at World Congress of the Academy for Global Business Advancement (AGBA). Woodbury School of Business, University of Utah Valley, 2017

Oshikoya, T (2014) "Economic Trilemma and Exchange Rate Management: What Option for Nigeria? Economic and Financial Review, Vol. 52 (4),105-125

Rodrik, D. (2008) "The Real Exchange Rate and Economic Growth" Brookings Paper on Economic Activity 39(2), 365-439.

Sarkar, A. and Amor T. (2009) "The Effect of Exchange Rate Disequilibrium and Financial Integration on Economic Growth" International Journal of Economics and Finance $1(2)$.

Toulaboe D (2011) Real exchange Rate Misalignment and Economic Growth in Developing Countries, Hays State University, 57-72.

Schnabel, G. (2008) "Exchange Rate Volatility and Growth in Small Open Economy" At the EMU periphery. Liepzing University.

Shobande, O.A and O.Y Alimi (2015) "Exogenous Macroeconomic Variables and Nigeria Output: An Extension of IS-MP-PC model and Taylor Rule". Journal of Developing countries. The International Institute for Science, Technology and Education. 5(7). 
Shobande, 0.A. (2017).

Imperative of Exchange Rates Policy and Industrial Growth in Nigeria: A Time Series Analysis

Shobande, O.A and A.T Odeleye (2015) "Long run Exchange rate and Economic Growth in Nigeria". Journal of Developing countries. The International Institute for Science, Technology and Education. 5(7).

Unugbro, A.O (2007) "The Impact of Exchange Rate Fluctuation on Capital Inflow: The Nigerian Experience. The Nigerian Academic Forum 13(2), 12-18.45-46.

World Development Indicator (2016) World Bank Data, World Bank Group. 